\title{
Psychological Distress and Zika, Dengue and Chikungunya Symptoms Following the 2016 Earthquake in Bahía de Caráquez, Ecuador
}

\author{
Anna M. Stewart-Ibarra ${ }^{1, *}$, Anita Hargrave ${ }^{2}$, Avriel Diaz ${ }^{3}$, Aileen Kenneson ${ }^{1}$ (D), \\ David Madden ${ }^{4}$, Moory M. Romero ${ }^{1}$, Juan Pablo Molina ${ }^{5}$ and David Macias Saltos ${ }^{5}$ \\ 1 Center for Global Health and Translational Science, SUNY Upstate Medical University, 750 East Adams St., \\ Syracuse, NY 13210, USA; aileen.kenneson@yahoo.com (A.K.); romero.moory@gmail.com (M.M.R.) \\ 2 Department of Medicine, University of California San Francisco, San Francisco, CA 94143, USA; \\ anita.hargrave@ucsf.edu \\ 3 Department of Ecology, Evolution and Conservation Biology at Columbia University, \\ New York, NY 10025, USA; avriel.diaz@gmail.com \\ 4 Walking Palms Global Initiative, Bahía de Caráquez 131401, Manabí Province, Ecuador; \\ davidpatrickmadden@gmail.com \\ 5 Ministry of Health, San Vicente 131458, Manabí Province, Ecuador; \\ molinajp2014@hotmail.com (J.P.M.); davidmacias126@gmail.com (D.M.S.) \\ * Correspondence: stewarta@upstate.edu; Tel.: +1-315-464-6489
}

Received: 10 November 2017; Accepted: 29 November 2017; Published: 5 December 2017

\begin{abstract}
On 16 April 2016, a 7.8 magnitude earthquake struck coastal Ecuador, resulting in significant mortality and morbidity, damages to infrastructure, and psychological trauma. This event coincided with the first outbreak of Zika virus (ZIKV) and co-circulation with dengue virus (DENV) and chikungunya virus (CHIKV). We tested whether the degree of psychological distress was associated with the presence of suspected DENV, CHIKV, ZIKV (DCZ) infections three months after the earthquake. In July 2016, 601 household members from four communities in Bahía de Caráquez, Manabí Province, Ecuador, were surveyed in a post-disaster health evaluation. Information was collected on demographics, physical damages and injuries, chronic diseases, self-reported psychological distress, and DCZ symptoms. We calculated the prevalence of arbovirus and distress symptoms by community. ANOVA was used to compare the mean number of psychological distress symptoms between people with versus without suspected DCZ infections by age, gender, community and the need to sleep outside of the home due to damages. The prevalence of suspected DCZ infections was 9.7\% and the prevalence of psychological distress was $58.1 \%$. The average number of psychological distress symptoms was significantly higher among people with suspected DCZ infections in the periurban community of Bella Vista, in women, in adults 40-64 years of age and in individuals not sleeping at home $(p<0.05)$. The results of this study highlight the need to investigate the interactions between psychological distress and arboviral infections following natural disasters.
\end{abstract}

Keywords: Zika virus; dengue; chikungunya; arbovirus; psychological distress; earthquake; Ecuador; natural disaster

\section{Introduction}

This study aims to describe the prevalence of psychological distress and arbovirus symptoms in vulnerable communities that were affected by the earthquake that occurred in Ecuador in April 2016. Since stress can affect the immune system adversely, we hypothesized that individuals who reported a greater degree of psychological distress would be more likely to report arbovirus symptoms. 
The earthquake and Zika epidemic in Ecuador. On 16 April 2016, one of the most devastating earthquakes of the last century occurred in coastal Ecuador (magnitude 7.8 Richter scale). There were 660 reported fatalities, 4605 people with injuries, 30,223 people displaced, 9738 buildings damaged/destroyed and roughly 720,000 people requiring humanitarian assistance [1]. The earthquake triggered a major epidemic of Zika virus (ZIKV) [2], a major health concern due to the complications associated with infection, such as Guillain-Barre Syndrome and congenital syndrome [3]. Following the earthquake, the cumulative number of ZIKV cases in Ecuador increased from 103 cases in epidemiological week 14 of 2016 to 1275 cases in epidemiological week 25 of 2016, with 85\% of all ZIKV cases in 2016 reported from Manabí Province, near the epicenter (Figures 1 and 2) [4]. There were repeated aftershocks in affected areas for months after the initial event. These communities experienced unparalleled stress from the increased burden of disease coupled with the material, psychological and physical damage they endured.

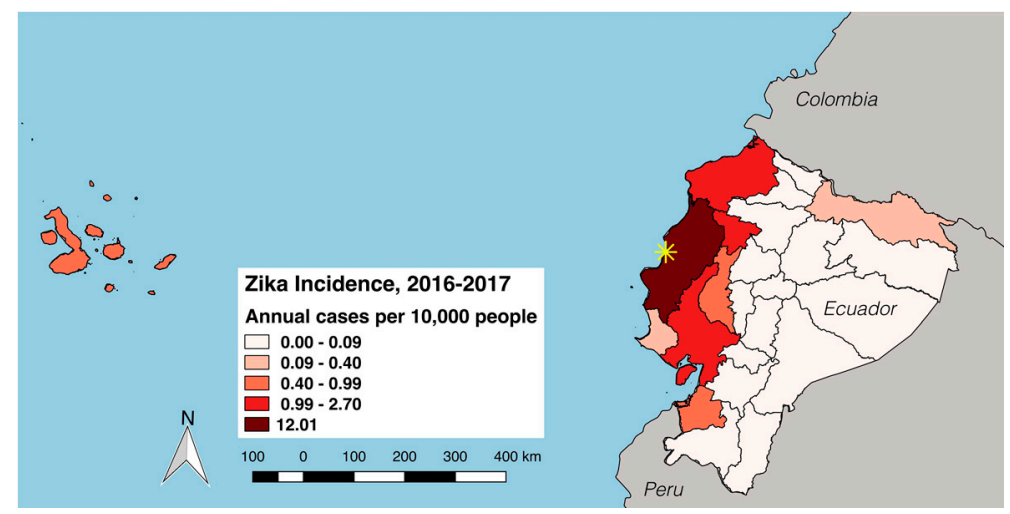

Figure 1. Annual ZIKV incidence per province in Ecuador, from epidemiological week (EW) 1 in 2016 to EW 38 in 2017 (cases per 10,000 people). The site of this study (Bahía de Caráquezf, Manabí Province) is indicated by the yellow asterisk. The earthquake epicenter was located $124 \mathrm{~km}$ northwest of Bahía de Caráquez. Data provided by the Ministry of Health of Ecuador [4].

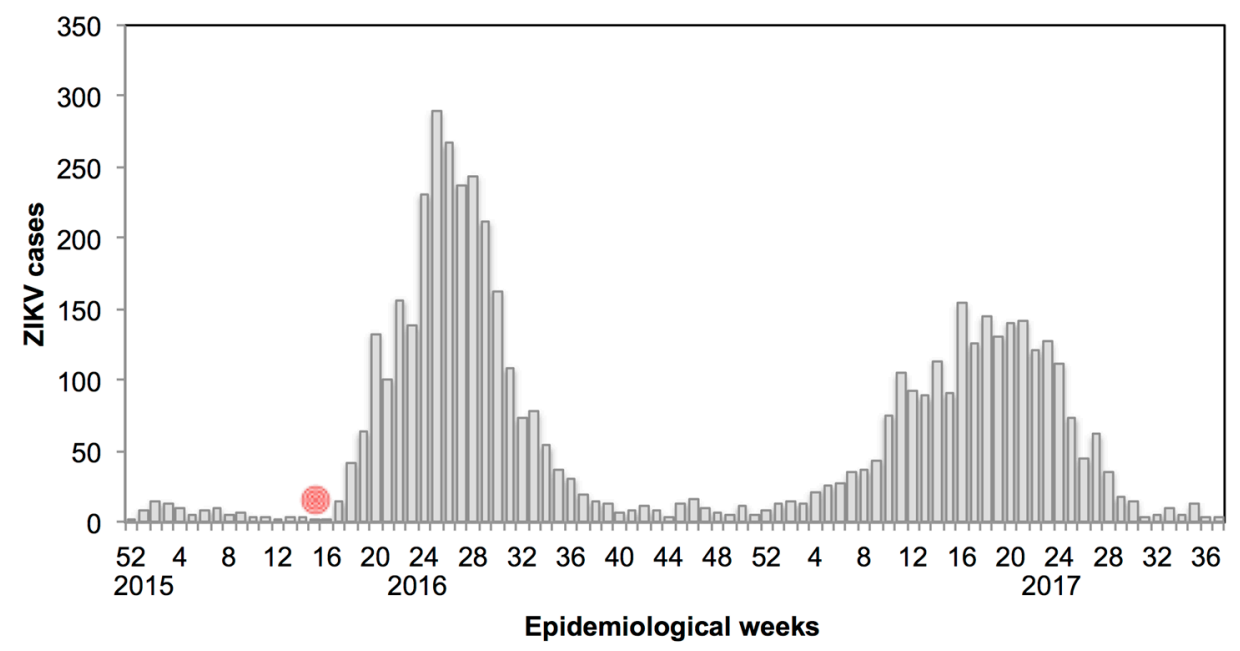

Figure 2. Weekly ZIKV cases in Ecuador through epidemiological week (EW) 38 in 2017. The date of the earthquake (EW 15, 2016) shown in red. In 2016, 85.1\% of ZIKV cases depicted here (2510 of 2944 cases) were reported from Manabí Province, the location of this study. Data provided by the Ministry of Health of Ecuador [4].

ZIKV (family: Flaviviridae, genus: flavivirus) is transmitted to people by the Aedes aegypti and Ae. albopictus mosquitoes, the same vectors as the dengue virus (DENV 1-4, family: Flaviviridae, genus: 
flavivirus) and chikungunya virus (CHIKV, family: Togaviridae, genus: alphavirus). These arboviruses have a similar clinical presentation (e.g., acute febrile illness) and many infections are mild or subclinical [3,5,6]. Coastal Ecuador is historically hyper-endemic for DENV due to high densities of Ae. aegypti in urban areas [7-10]. Ae. aegypti is an anthropophilic mosquito vector, whose preferred larval habitat is standing water in man-made containers (e.g., 55 gallon drums, buckets, tires, flower vases) [5]. The risk of arboviral infections increased following the earthquake due, in part, to damages to the piped water system. As a result, people stored water in uncovered containers around the home, increasing the availability of mosquito larval habitat. Many people lost their homes and were forced to relocate to formal and informal tent camps, increasing their exposure to mosquito bites. Pre-existing poverty and other social vulnerabilities were exacerbated [11]. The earthquake also coincided with an exceptionally strong El Niño event, resulting in warmer than average air temperatures in coastal Ecuador, which increased the risk of arbovirus outbreaks [11-14].

In Ecuador, it is mandatory that DENV, CHIKV and ZIKV (DCZ) cases be reported to the Ministry of Health $(\mathrm{MoH})$, which follows World Health Organization (WHO) guidelines for diagnosis and reporting. DCZ cases are diagnosed by clinical symptoms and epidemiological nexus; a subset of cases are diagnosed by laboratory assays at the National Public Health Research Institute (INSPI) of the $\mathrm{MoH}$. Vector control and educational campaigns are the primary public health interventions to prevent and control disease outbreaks (e.g., chemical control and elimination of larval habitat, fogging and indoor residual spraying). In the period following the earthquake, the $\mathrm{MoH}$ conducted a campaign to distribute bed nets to pregnant women to prevent ZIKV transmission in the affected areas.

Psychological distress and infectious diseases post-disasters. Natural disasters bring with them damages to housing and infrastructure, lack of sanitation, crowding in formal and informal resettlements, and damage to health care facilities, especially in resource-limited settings. It is not surprising that increases in morbidity and mortality from infectious diseases have often been observed in their wake $[15,16]$. For example, in 2010, a major earthquake struck Haiti, taking the lives of an estimated 230,000 persons and displacing over 1.5 million others. The earthquake was followed by a devastating cholera (Vibrio cholerae) epidemic [17]. Similarly, after the 2004 floods in Bangladesh, there was a spike in enterotogenic Escherichia coli (ETEC) and V. cholerae, leading to an epidemic of diarrheal illness [18].

Populations affected by natural disasters may also experience psychological morbidity [19-21]. Earthquake survivors commonly suffer from post-traumatic stress disorder (PTSD) [20,22-24], characterized by re-experiencing the event, with persistent avoidance of factors associated with the event and negative thoughts/feelings after the trauma [25]. Anxiety, depression and suicidal ideation have also been noted to severely impact the lives of earthquake survivors [20,22]. Early studies in Colombia and Ecuador revealed the impact of natural disasters on mental health in Andean countries, with a higher prevalence of psychological distress in areas with more severe natural disasters [26-28]. In these populations, the most common psychological diagnoses post-disaster were PTSD and major depression.

Stress has been shown to significantly influence the response of the immune system by triggering the release of hormones and other substances in the brain. In addition, people's behaviors often change in response to stressful situations, for example, changes in sleeping patterns, poor nutrition, and substance abuse [29]. Such changes can potentially alter the response of the immune system to infectious pathogens [30]. Stress has been associated with higher rates of respiratory tract infections, herpes virus flares and malignancies [30-32]. Early studies showed that psychological stress was associated in a dose-response relationship with increased risk of acute respiratory illness [33]. Higher cortisol levels, which can suppress the immune response, have been associated with more severe pneumonia and DENV infections [34,35]. Cellular immune dysfunction has also been noted among patients with PTSD [36]. Mouse model studies found that stress can increase morbidity due to viral infection [37-39]. 
Despite the robust literature supporting the surge in psychological distress and infectious diseases following certain natural disasters, there are very few studies that integrate these three areas. Here we present the results of an analysis of a cross-sectional survey on psychological distress and DCZ symptoms conducted in communities affected by the earthquake in Manabí Province, Ecuador, in July 2016, three months after the earthquake.

\section{Methods}

\subsection{Study Area}

Bahía de Caráquez (population 20,921) is a small tourist city located along the north-central coast of Ecuador in Manabí province (Figure 1). The city was heavily damaged in the earthquake. The public hospital was so severely damaged that it had to be closed. As a result, most health interventions in the communities affected by the earthquake were limited to primary care. ZIKV incidence rates in Manabí province remain the highest in the country (average annual incidence in 2016 and 2017: 12.0 cases per 10,000 people) [4].

\subsection{Participants}

Four communities in Bahía de Caráquez were included in this study: Jorge Lomas, Pajonal, La Merced and Bellavista. Jorge Lomas is an urban community located near the city center. Community members are a mix of local permanent residents and families with vacation homes. The majority of those surveyed were permanent residents, as most vacationers had fled the area. The primary income for local residents comes from a mix of urban jobs (teachers, shop owners, restaurant business, etc.). Pajonal is a rural fishing community. Nearby areas are being developed by private luxury housing companies along the coastline, providing jobs in construction. Some homes were damaged, but the community church, school and center remained intact. La Merced is a rural community that is located near a health center that was severely impacted by the earthquake. The community is located on the outskirts of Bahía de Caráquez, and many of the residents are employed by shrimp farms or are local fishermen. Following the earthquake many homes were damaged and water shortages resulted in increased water storage around homes. Bella Vista is a community located on a steep hillside at the urban periphery. For many years, this community has not been recognized as a formal urban settlement. Informal employment is the default source of income (e.g., fishing, construction, and petty trade work). We observed that most of the homes on the hillsides were completely demolished following the earthquake.

\subsection{Data Source}

De-identified data were provided by the Ministry of Health of Ecuador (Zone XI, San Vicente, Sucre, Manabí Province). Data were collected by Ministry of Health field technicians and disaster relief volunteers as part of a post-disaster health evaluation. Surveys were conducted from 19-25 July 2016. Homes were selected if household members were at home during the day when the technicians conducted face-to-face surveys. All household members were surveyed $(\mathrm{N}=601)$, and the responsible adult in the home responded on behalf of young children. In most instances, the head of the household relayed information about people living in the household if they were not present. No identifiable human subject information was included in the dataset analyzed in this study. The local Ministry of Health approved of this study. The Institutional Review Board of SUNY Upstate Medical University (Syracuse, NY, USA) deemed that this study was exempt from review, as no identifiable information was included. 


\subsection{Measures}

We analyzed the following individual-level data: demographics, basic medical history (pregnancy, chronic diseases, disabilities), the presence/absence of self-reported psychological distress symptoms post-earthquake (subjective feelings of stress, fear, insomnia, anorexia, chest pain, fear of being alone, anxiety, nightmares, headache, difficulty concentrating, hopelessness and sadness), damages to the home and physical injury due to the earthquake, whether individuals were sleeping at home or elsewhere, whether they had an episode of DCZ illness post-earthquake and the symptoms associated with the illness (headache, anorexia or nausea, conjunctivitis, rash, bleeding, vomiting, lethargy, abdominal pain, diarrhea, retro-orbital pain, muscle/joint pain), date of DCZ symptom onset, and whether they sought medical care. Psychological and DCZ symptoms were recorded if symptoms commenced after the April 2016 earthquake. Psychological distress symptoms were culturally adapted from the Anxiety and Depression Association of America. We classified an individual with a suspected DCZ infection if an individual reported fever plus two or more additional symptoms. This definition follows the WHO classification for dengue fever [5]. Damage to the home were defined as mild if occupants were able to return to the home immediately, moderate if some repairs had to be made before returning home, and severe if occupants had not yet been able to return.

\subsection{Data Analysis}

Statistical analyses were conducted using SAS 9.4 (SAS Institute Inc., Cary, NC, USA). We assessed whether the number of distress symptoms was associated with the presence/absence of suspected DCZ infections by study site, gender, age class, and whether the individual was sleeping at home. The variable "headache" was excluded from DCZ and distress symptoms due to a high degree of correlation. Bivariate analyses were conducted using $t$-tests (continuous variables) or Chi-squared tests (categorical variables), and comparisons across multiple groups were conducted by ANOVA. Adjustments were not made for multiple comparisons, and results should be interpreted accordingly.

\section{Results}

\subsection{Demographics and Earthquake Damages}

A total of 601 individuals from 160 households were included in this analysis, with 360 individuals (59.9\%) from the two urban sites and 241 individuals (40.1\%) from the two rural sites (Table 1). Participants were 28.9 years of age on average $(\mathrm{SD}=21.2$, median $=23) ; 48.4 \%$ were female and $51.6 \%$ were male. Eight women were pregnant, accounting for $5.4 \%$ of women of reproductive age (15 to 49 years of age). Five percent $(30 / 601)$ of the population reported one or more disabilities (3 auditory, 7 visual, 5 mental, 12 physical, 3 not reported). One quarter $(92 / 349,26.4 \%$ ) of the adult population ( $>18$ years of age) reported one or more chronic health conditions (Table 1). Hypertension $(50 / 349,14.3 \%)$ and diabetes $(32 / 349,9.2 \%)$ were the most prevalent chronic health conditions in adults (see Supplementary Materials Table S1 for chronic conditions by site).

The majority of homes surveyed in this study suffered damages due to the earthquake $(143 / 160,89.4 \%)$ (Table 2$)$. Almost half of the homes had severe damages $(63 / 150,42 \%)$ and as a result, individuals from almost half of the homes were sleeping somewhere other than at home $(70 / 160,43.8 \%)$. In one in five homes, someone was injured during the earthquake $(30 / 160,18.8 \%)$. Bella Vista suffered the greatest damages to homes $(95.6 \%$ of homes damaged; $45.7 \%$ of damages were severe; $60.8 \%$ were not sleeping at home). Households in La Merced had the highest frequency of injuries (34\% of homes with someone injured). Pajonal was the site with the least damage (61.9\% of homes damaged; $52.6 \%$ of damages were mild/moderate; $9.5 \%$ were not sleeping at home). 
Table 1. Demographic and clinical characteristics of study participants by site.

\begin{tabular}{|c|c|c|c|c|c|}
\hline Variables & Bella Vista & Jorge Lomas & La Merced & Pajonal & Total \\
\hline Setting & Urban & Urban & Rural & Rural & - \\
\hline All participants $(\mathrm{N})$ & 274 & 86 & 171 & 70 & 601 \\
\hline Adults ( $>18$ years) $(\%$ of $N)$ & $149(54.4 \%)$ & $62(72.1 \%)$ & $99(57.9 \%)$ & $39(55.7 \%)$ & $349(58.1 \%)$ \\
\hline $\begin{array}{l}\text { Women ( } 15 \text { to } 49 \text { years) of } \\
\text { reproductive age (\% of } \mathrm{N})\end{array}$ & $70(25.5 \%)$ & $24(27.9 \%)$ & $34(19.9 \%)$ & $21(30.0 \%)$ & $149(24.8 \%)$ \\
\hline Age, mean (SD), years & $34.1(22.6)$ & $27.6(20.8)$ & $31.6(22.5)$ & $25.9(19.5)$ & $28.9(21.2)$ \\
\hline Female sex $(\%$ of $N)$ & $132(48.2 \%)$ & $48(55.8 \%)$ & $78 / 167(46.7 \%)$ & $31(44.3 \%)$ & $289 / 597(48.4 \%)$ \\
\hline $\begin{array}{l}\text { Pregnant (\% of women of } \\
\text { reproductive age) }\end{array}$ & $3(4.30 \%)$ & $1(4.2 \%)$ & $3(8.8 \%)$ & $1(4.8 \%)$ & $8(5.4 \%)$ \\
\hline Disabled $(\%$ of $N)$ & $12(4.4 \%)$ & $4(4.7 \%)$ & $12(7.0 \%)$ & $2(2.9 \%)$ & $30(5.0 \%)$ \\
\hline Hypertension (\% of adults) & $19(12.8 \%)$ & $8(12.9 \%)$ & $18(18.2 \%)$ & $5(12.8 \%)$ & $50(14.3 \%)$ \\
\hline Diabetes (\% of adults) & $13(8.7 \%)$ & $3(4.8 \%)$ & $14(14.1 \%)$ & $2(5.1 \%)$ & $32(9.2 \%)$ \\
\hline $\begin{array}{l}\text { Any chronic disease } \\
\text { (\% of adults) }\end{array}$ & $41(27.5 \%)$ & $9(14.5 \%)$ & $34(34.3 \%)$ & $8(20.5 \%)$ & $92(26.4 \%)$ \\
\hline
\end{tabular}

Table 2. Earthquake damages. Households ( $\mathrm{n}$ and \%) that reported that someone was injured, whether household members were sleeping at home, and damages to the home as a result of the earthquake.

\begin{tabular}{cccccc}
\hline Damages & Bella Vista & Jorge Lomas & La Merced & Pajonal & Total \\
\cline { 2 - 5 } & $\mathbf{N}=\mathbf{7 4}$ & $\mathbf{N}=\mathbf{2 1}$ & $\mathbf{N}=\mathbf{4 4}$ & $\mathbf{N}=\mathbf{2 1}$ & $\mathbf{N}=\mathbf{1 6 0}$ \\
\hline $\begin{array}{c}\text { Someone in the home } \\
\text { was physically injured. }\end{array}$ & $10 / 74(13.5 \%)$ & $4 / 21(19.0 \%)$ & $15 / 44(34.0 \%)$ & $1 / 21(4.8 \%)$ & $30 / 160(18.8 \%)$ \\
\hline $\begin{array}{c}\text { Not sleeping at home } \\
\text { due to damages. }\end{array}$ & $45 / 74(60.8 \%)$ & $4 / 21(19.0 \%)$ & $19 / 44(43.2 \%)$ & $2 / 21(9.5 \%)$ & $70 / 160(43.8 \%)$ \\
\hline $\begin{array}{c}\text { Home was damaged. } \\
\text { Mild damage* }\end{array}$ & $71 / 74(95.9 \%)$ & $19 / 21(90.5 \%)$ & $40 / 44(90.9 \%)$ & $13 / 21(61.9 \%)$ & $143 / 160(89.4 \%)$ \\
$\begin{array}{c}\text { Moderate damage * } \\
\text { Severe damage * }\end{array}$ & $19 / 70(27.1 \%)$ & $13 / 19(68.4 \%)$ & $15 / 42(35.7 \%)$ & $8 / 19(42.1 \%)$ & $55 / 150(36.7 \%)$ \\
\hline
\end{tabular}

* The proportion of respondents with mild, moderate and severe damages to their homes were calculated based on the number of respondents that had homes that were damaged and classified (Bella Vista $\mathrm{N}=70$, Jorge Lomas $\mathrm{N}=19$, La Merced $\mathrm{N}=42$, Pajonal $\mathrm{N}=19$ ). Damage to the home were defined as mild if occupants were able to return to the home immediately, moderate if some repairs had to be made before returning home, and severe if occupants had not yet been able to return.

\subsection{Psychological Distress}

More than half of the respondents had one or more symptoms of psychological distress $(343 / 590,58.1 \%$, Table 3). The most frequently reported symptoms were fear $(308 / 590,52.2 \%)$, stress $(98 / 590,16.6 \%)$, insomnia $(95 / 590,16.1 \%)$ and monophobia (fear of being alone) $(38 / 590,6.4 \%)$. There were significant differences in the frequency of symptoms reported by study site $(p<0.05)$, with a higher mean number of distress symptoms in the rural sites (1.46 in La Merced and 1.31 in Pajonal, versus 0.85 in Bella Vista and 0.97 in Jorge Lomas). There was a significant difference in the number of distress symptoms by age class $(p<0.05)$. Adolescents $(10-18$ years) reported the greatest number of stress symptoms (mean $=1.46, \mathrm{SD}=1.75)$ and young adults (19-39 years) the least (mean $=0.84$, $\mathrm{SD}=1.18$ ). There were no significant differences in the number of stress symptoms by gender (female: mean $=1.20, \mathrm{SD}=1.33$; male: mean $=0.98, \mathrm{SD}=1.38, p>0.05$ ) or by sleeping at home versus not at home (at home: mean $=1.18, \mathrm{SD}=1.41$; not at home: mean $=1.03, \mathrm{SD}=1.35, p>0.05$ ). We calculated the average number of psychological distress symptoms for adolescents sleeping at home versus not sleeping at home and found that there were no significant differences (at home: mean $=1.51, \mathrm{SD}=1.94$; not at home: mean $=0.97, \mathrm{SD}=1.16, p=0.07$ ). 
Table 3. Prevalence of psychological distress symptoms by study site. Respondents ( $\mathrm{n}$ and \%) who reported distress symptoms by site.

\begin{tabular}{cccccc}
\hline \multirow{2}{*}{ Symptoms } & Bella Vista & Jorge Lomas & La Merced & Pajonal & Total \\
\cline { 2 - 6 } & $\mathbf{N}=\mathbf{2 6 3}$ & $\mathbf{N = \mathbf { 8 6 }}$ & $\mathbf{N = 1 7 1}$ & $\mathbf{N = \mathbf { 7 0 }}$ & $\mathbf{N}=\mathbf{5 9 0}$ \\
\hline Fear & $114(43.3 \%)$ & $49(57.0 \%)$ & $89(52.0 \%)$ & $56(80.0 \%)$ & $308(52.2 \%)$ \\
Stress & $42(16.0 \%)$ & $13(15.1 \%)$ & $25(14.6 \%)$ & $18(25.7 \%)$ & $98(16.6 \%)$ \\
Insomnia & $29(11.0 \%)$ & $19(22.1 \%)$ & $38(22.2 \%)$ & $9(12.9 \%)$ & $95(16.1 \%)$ \\
Monophobia (fear of being alone) & $11(4.2 \%)$ & 0 & $21(12.3 \%)$ & $6(8.6 \%)$ & $38(6.4 \%)$ \\
Anorexia & $8(3.0 \%)$ & 0 & $12(7.0 \%)$ & $3(4.3 \%)$ & $23(3.9 \%)$ \\
Headache & $4(1.5 \%)$ & 0 & $17(9.9 \%)$ & 0 & $21(3.6 \%)$ \\
Anxiety & $12(4.6 \%)$ & $2(2.3 \%)$ & $6(3.5 \%)$ & 0 & $20(3.4 \%)$ \\
Angina (chest pain) & 0 & 0 & $12(7.0 \%)$ & 0 & $12(2.0 \%)$ \\
Hopelessness & $1(0.4 \%)$ & 0 & $10(5.8 \%)$ & 0 & $11(1.9 \%)$ \\
Sadness & $2(0.8 \%)$ & 0 & $8(4.7 \%)$ & 0 & $10(1.7 \%)$ \\
Difficulty concentrating & $1(0.4 \%)$ & 0 & $8(4.7 \%)$ & 0 & $9(1.5 \%)$ \\
Nightmares & $3(1.1 \%)$ & 0 & $3(1.8 \%)$ & 0 & $6(1.0 \%)$ \\
1 or more symptom & $138(52.5 \%)$ & $50(58.1 \%)$ & $99(57.9 \%)$ & $56(80.0 \%)$ & $343(58.1 \%)$ \\
Mean number of symptoms (SD) & $0.85(1.73 \%)$ & $0.97(1.04 \%)$ & $1.46(1.87 \%)$ & $1.31(1.03 \%)$ & $1.07(1.29 \%)$ \\
\hline
\end{tabular}

\subsection{Arbovirus Symptoms}

We identified 50 individuals with a suspected DCZ infection post-earthquake (50/601, 9.7\%) (Table 4). No pregnant women had a suspected DCZ infection post-earthquake. Of those with suspected DCZ infections, $62 \%$ had sought medical care. The most frequently reported symptoms were fever $(66 / 601,11.0 \%)$, headache $(65 / 601,10.8 \%)$, muscle/joint pain $(61 / 601,10.1 \%)$, and rash $(47 / 601,7.8 \%)$. There was a significant difference in the prevalence of suspected DCZ infections among sites $(p<0.05)$. The highest prevalence of suspected DCZ infections was found in Bella Vista $(28 / 274,10.2 \%)$, followed by La Merced $(12 / 171,7 \%)$. Individuals who reported that they were not sleeping at home were significantly more likely to have suspected DCZ infections (90/269,33\%) than those who were sleeping at home $(47 / 326,14.4 \%)(p<0.00001)$. There were no significant differences in the frequency of suspected DCZ infections by age group or by gender.

Table 4. Prevalence of dengue, chikungunya or Zika fever (DCZ) symptoms by study site; respondents ( $\mathrm{n}$ and \%) who reported DCZ symptoms in the post-earthquake period, those who were defined as suspected DCZ infections (fever plus two additional symptoms), and individuals with suspected DCZ infections who sought medical care.

\begin{tabular}{cccccc}
\hline Symptoms & Bella Vista & Jorge Lomas & La Merced & Pajonal & Total \\
\cline { 2 - 5 } & $\mathbf{N}=\mathbf{2 7 4}$ & $\mathbf{N}=\mathbf{8 6}$ & $\mathbf{N = 1 7 1}$ & $\mathbf{N}=\mathbf{7 0}$ & $\mathbf{N}=\mathbf{6 0 1}$ \\
\hline Fever & $37(13.5 \%)$ & $9(10.5 \%)$ & $16(9.4 \%)$ & $4(5.7 \%)$ & $66(11.0 \%)$ \\
\hline Headache & $35(12.8 \%)$ & $7(8.1 \%)$ & $20(11.7 \%)$ & $3(4.3 \%)$ & $65(10.8 \%)$ \\
\hline Muscle/joint pain & $37(13.5 \%)$ & $9(10.5 \%)$ & $16(9.4 \%)$ & $4(5.7 \%)$ & $61(10.1 \%)$ \\
\hline Rash & $26(9.5 \%)$ & $4(4.7 \%)$ & $17(9.9 \%)$ & 0 & $47(7.8 \%)$ \\
\hline Anorexia or nausea & $9(3.3 \%)$ & $1(1.2 \%)$ & $4(2.3 \%)$ & 0 & $14(2.3 \%)$ \\
\hline Abdominal pain & $8(2.9 \%)$ & $1(1.2 \%)$ & $4(2.3 \%)$ & 0 & $13(2.2 \%)$ \\
\hline Vomiting & $8(2.9 \%)$ & $1(1.2 \%)$ & $3(1.8 \%)$ & 0 & $12(2.0 \%)$ \\
\hline Conjunctivitis & $7(2.6 \%)$ & $1(1.2 \%)$ & $3(1.8 \%)$ & 0 & $11(1.8 \%)$ \\
\hline Retro-orbital pain & $5(1.8 \%)$ & $1(1.2 \%)$ & $4(2.3 \%)$ & 0 & $10(1.7 \%)$ \\
\hline Diarrhea & $4(1.5 \%)$ & $1(1.2 \%)$ & $4(2.3 \%)$ & 0 & $9(1.5 \%)$ \\
\hline Lethargy & $3(1.1 \%)$ & 0 & 0 & 0 & $3(0.5 \%)$ \\
\hline Bleeding & $1(0.4 \%)$ & 0 & 0 & 0 & $1(0.2 \%)$ \\
\hline Any symptom & $49(17.9 \%)$ & $9(10.5 \%)$ & $26(15.2 \%)$ & $4(5.7)$ & $88(14.6 \%)$ \\
\hline $\begin{array}{c}\text { Those with suspected DCZ } \\
\text { (feverted DCZ infection }\end{array}$ & $28(10.2 \%)$ & $7(0.8 \%)$ & $12(7.0 \%)$ & $3(4.3)$ & $50(9.7 \%)$ \\
\hline $\begin{array}{c}\text { Mean symptoms) } \\
\text { num. symptoms (SD) }\end{array}$ & $3.6(2.1 \%)$ & $3.7(2.3 \%)$ & $3.4(2.6 \%)$ & $2.5(1.0 \%)$ & $3.4(2.2 \%)$ \\
\hline who sought medical care & $17 / 28(60.7 \%)$ & $4 / 7(57.1 \%)$ & $10 / 12(83.3 \%)$ & 0 & $31 / 50(62.0 \%)$ \\
\hline
\end{tabular}




\subsection{Distress and Arboviral Symptoms}

We evaluated whether the average number of psychological distress symptoms varied in individuals with and without suspected DCZ infection by study site, gender, age and sleeping at home (Table 5, Figure 3). In the comparison across study sites, we found that in the community of Bella Vista, individuals with suspected DCZ infections reported a greater mean number of psychological distress symptoms than those without suspected DCZ infections (with DCZ: mean $=1.18, \mathrm{SD}=1.18$; without DCZ: mean $=0.70, \mathrm{SD}=0.92, p=0.01$ ). Although individuals with suspected DCZ infection in Jorge Lomas and Pajonal also reported a greater average number of distress symptoms, the findings did not reach statistical significant $(p>0.05)$. In a comparison by gender, we identified a significantly greater number of distress symptoms in women with suspected DCZ infections (with DCZ: mean $=1.60$, $\mathrm{SD}=1.55$; without DCZ: mean $=1.00, \mathrm{SD}=1.09, p=0.01$ ). There were no significant differences in men $(p>0.05)$. In a comparison across age classes, individuals 40-64 years of age with suspected DCZ infections had a significantly greater average number of distress symptoms (with DCZ: mean $=2.75$, $\mathrm{SD}=1.29$; without DCZ: mean $=1.12, \mathrm{SD}=1.17, p<0.0001$ ). The differences were not significant in the other age classes $(p>0.05)$. Individuals with suspected DCZ infections who were not sleeping at home had significantly greater number of distress symptoms (with DCZ: mean $=1.10, \mathrm{SD}=1.18$; without DCZ: mean $=0.66, \mathrm{SD}=0.91, p=0.02$ ). There were no significant differences in individuals sleeping at home $(p>0.05)$.
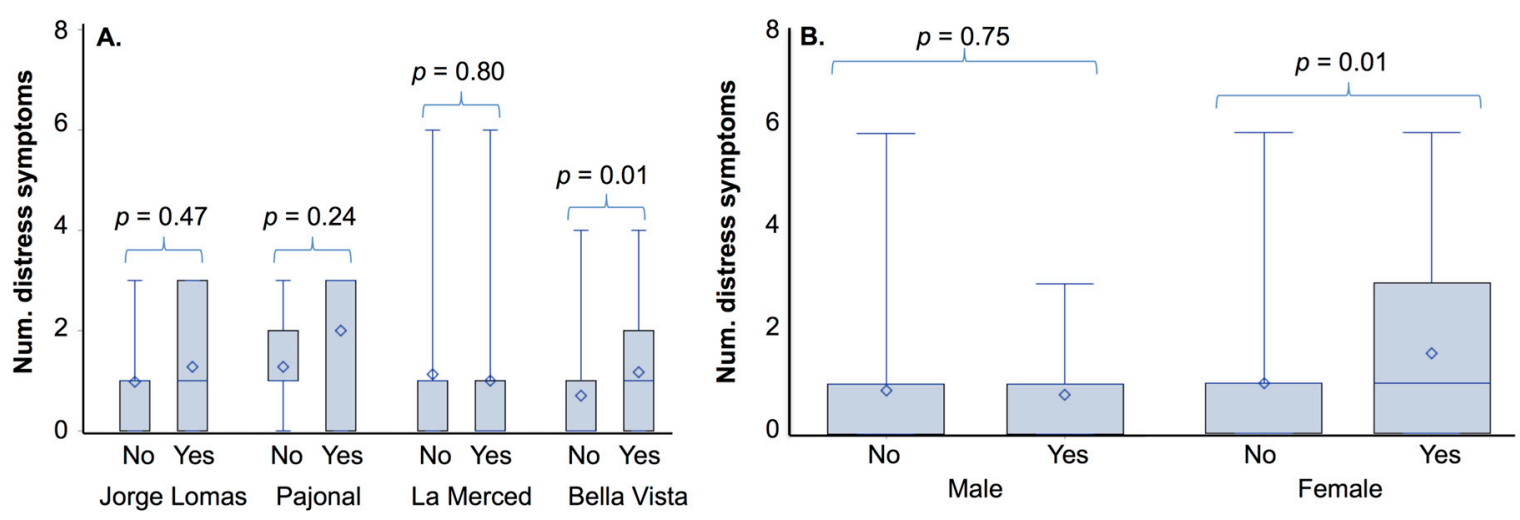

Presence/absence of suspected DCZ infection

Presence/absence of suspected DCZ infection
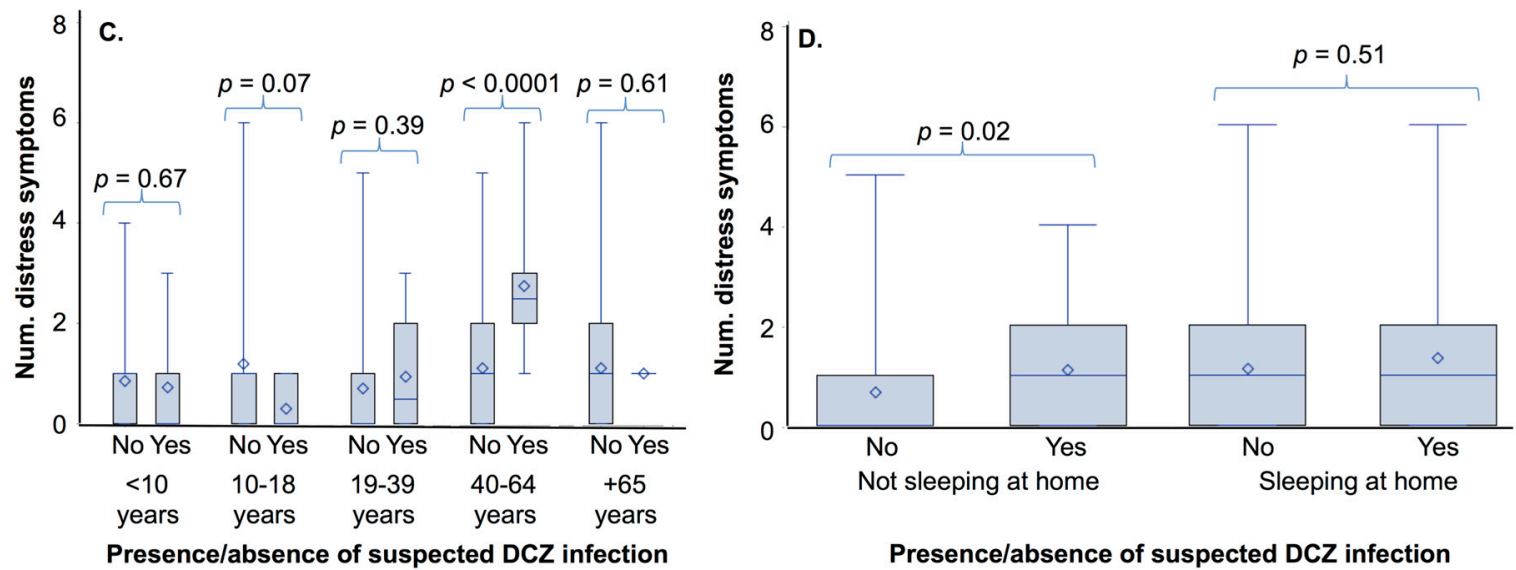

Presence/absence of suspected DCZ infection

Figure 3. Average number of psychological distress symptoms among participants with and without suspected dengue, chikungunya, or Zika (DCZ) infections by (A) study sites, (B) gender, (C), age classes and $(\mathbf{D})$ and whether or not the individual was sleeping at home or elsewhere. Significant differences indicated by $p<0.05$. 
Table 5. Distress symptoms reported by participants with versus without suspected dengue, chikungunya, Zika fever (DCZ) infections following the earthquake. Means and standard deviations (SD) shown. Significant differences indicated by $p<0.05$.

\begin{tabular}{|c|c|c|c|c|c|}
\hline \multirow{2}{*}{ A. Sites } & All & Bella Vista & Jorge Lomas & La Merced & Pajonal \\
\hline & $N=464$ & $N=203$ & $\mathrm{~N}=72$ & $\mathrm{~N}=122$ & $N=67$ \\
\hline DCZ (SD) & $0.95(1.19)$ & $0.70(0.92)$ & $0.99(1.03)$ & $1.12(1.60)$ & $1.28(1.00)$ \\
\hline No DCZ (SD) & $1.20(1.34)$ & $1.18(1.18)$ & 1.29 (1.29) & $1.00(1.81)$ & $2.00(1.73)$ \\
\hline$p$-value & $p=0.16$ & $p=0.01$ & $p=0.58$ & $p=0.80$ & $p=0.24$ \\
\hline \multirow{2}{*}{ B. Gender } & Male & Female & & & \\
\hline & $\mathrm{N}=268$ & $\mathrm{~N}=245$ & & & \\
\hline $\mathrm{DCZ}(\mathrm{SD})$ & $0.88(1.24)$ & $1.00(1.09)$ & & & \\
\hline No DCZ (SD) & $0.80(0.96)$ & $1.60(1.55)$ & & & \\
\hline$p$-value & $p=0.75$ & $p=0.01$ & & & \\
\hline \multirow{2}{*}{ C. Age classes } & $<10$ years & $10-18$ years & 19-39 years & 40-64 years & $65+$ \\
\hline & $\mathbf{N}=\mathbf{1 3 0}$ & $\mathrm{N}=122$ & $\mathrm{~N}=178$ & $\mathbf{N}=110$ & $N=61$ \\
\hline $\mathrm{DCZ}(\mathrm{SD})$ & $0.86(0.97)$ & $1.19(1.53)$ & $0.69(0.94)$ & $1.12(1.17)$ & $1.10(1.36)$ \\
\hline No DCZ (SD) & $0.73(1.01)$ & $0.30(0.48)$ & $0.93(1.14)$ & $2.75(1.29)$ & $1.00(0)$ \\
\hline$p$-value & $p=0.67$ & $p=0.07$ & $p=0.39$ & $p<0.0001$ & $p=0.61$ \\
\hline \multirow{2}{*}{ D. Sleeping at home } & Not sleeping at home & Sleeping at home & & & \\
\hline & $\mathrm{N}=297$ & $N=201$ & & & \\
\hline DCZ (SD) & $0.66(0.91)$ & $1.14(1.30)$ & & & \\
\hline No DCZ (SD) & $1.10(1.18)$ & $1.33(1.56)$ & & & \\
\hline$p$-value & $p=0.02$ & $p=0.51$ & & & \\
\hline
\end{tabular}

\section{Discussion}

This investigation of recent earthquake survivors sheds light on the degree of psychological distress and its association with suspected arbovirus infections following a natural disaster. This study is important given the unique nature of the co-occurrence of a severe earthquake event and the ZIKV epidemic. The earthquake occurred three and a half months after the first ZIKV cases were reported in Ecuador and triggered a major outbreak of ZIKV, in addition to outbreaks of DENV and CHIKV. In 2016, a total of 14,150 DENV cases [40], 2025 CHIKV cases [41] and 3531 ZIKV cases were reported in Ecuador [42]. We report positive associations between the degree of psychological distress and the presence of suspected dengue, chikungunya, Zika (DCZ) infections among affected populations near the earthquake epicenter. This underscores the need for an integrated approach to disaster relief interventions, which includes mental health professionals as well as health professionals with training in diagnosing and treating infectious diseases in post-disaster settings.

\subsection{Psychological Distress}

We found a high prevalence of psychological distress (58.1\%) three months following the earthquake. This is consistent with prior studies that documented the effects of earthquakes and other natural disasters on mental health in Andean and other resource-limited countries. In a study conducted in Colombia seven to ten months after a volcanic eruption, approximately half of the individuals residing in resettlement camps and individuals visiting outpatient clinics reported symptoms of emotional distress [26]. In northern Ecuador, three months after an earthquake in 1987, $38 \%$ of adults who visited outpatient clinics had signs of psychological distress. This population was much less affected than the population surveyed here, as there was no loss of life in the study area. Investigations of earthquake survivors in Peru (five months post event), found that $25.2 \%$ of adults had PTSD [43]. In China, the prevalence of PTSD post-earthquake ranged from 44 to $60.4 \%$ [44], and the prevalence of psychological distress symptoms in adults following an earthquake in India was $59 \%$ [45]. The most common psychological diagnoses for earthquake survivors were PTSD and major 
depression $[24,28,45]$. Most studies suggest that PTSD symptoms decrease within the first two years following the event $[23,46-49]$. The risk of psychological distress has been shown to increase with proximity to the epicenter, by gender (female), in individuals who lack of social support, in individuals who lost their homes, those who suffered injuries and those who lacked access to food and water, among other factors [21,26,43-45].

In this study individuals from rural communities and adolescents reported a greater number of psychological distress symptoms. Studies have shown that PTSD symptoms are common in adolescents who have survived earthquakes, with prevalence rates ranging from 16.9 to $70.3 \%$ [23,50-52]. We observed that in people in rural communities felt isolated from earthquake relief efforts, which were focused in the more populated urban areas. It is possible that the distress that we documented may reflect pre-existing levels of distress in rural areas. A prior study on mental health in rural coastal Ecuador found that older adults ( $>59$ years) had a $12 \%$ prevalence of depression, $15 \%$ prevalence of anxiety, and $5 \%$ prevalence of stress [53]. In the same age group, individuals in this study self-reported a $24.6 \%$ prevalence of stress, $4.9 \%$ prevalence of anxiety and $4.9 \%$ prevalence of hopelessness / sadness. Fear, the most common symptom documented here, was not reported as a separate entity in the prior study. These results suggest that adolescents and rural communities should be considered as part of targeted mental health interventions in a post-disaster setting.

\subsection{Arbovirus Symptoms}

We found that one in ten individuals (9.7\%) met our definition for a suspected DCZ infection in the three months following the earthquake. These prevalence estimates are comparable to DENV prevalence estimates from an active surveillance study in southern coastal Ecuador [54], which reported a $8.9 \%$ prevalence of acute symptomatic (apparent) DENV infections in homes near confirmed DENV infections. The prevalence of suspected DCZ infections was greatest in the community of Bella Vista (10.2\%) and in individuals who reported that they were not sleeping at home (33.0\%). Periurban communities are often at greatest risk of acquiring Ae. aegypti transmitted diseases due to ample mosquito larval habitat near homes (e.g., discarded containers, tires, water storage drums), high population density, and substandard housing conditions which permit entry of the mosquito vector into the home [5,55-57]. People not sleeping at home were likely at greater risk of exposure to infectious mosquito bites, since in many instances, they were sleeping outdoors in crowded, informal tent camps.

Differential diagnosis of DCZ infections in a post-disaster setting is a major challenge, since these diseases are transmitted by the same mosquito vector, they co-occur in the same geographic region, the clinical presentation is similar, and there may be limited/no access to diagnostic tests. This study was limited by lack of laboratory confirmation of DCZ infections. For this reason, we do not differentiate between the infections; we report of the prevalence of DCZ symptoms and the prevalence of suspected DCZ infections. In an attempt to take a more rigorous approach to the clinical diagnosis, we applied the WHO guidelines for the diagnosis of DENV (fever plus two or more other listed symptoms) to define suspected DCZ infections. The guidelines for CHIKV and ZIKV diagnosis are less strictly defined; therefore, this study likely underestimated the prevalence of viral illness. It is also possible that we captured other infections that cause similar symptoms, such as respiratory infections, typhus fever, leptospirosis, or malaria [58]. In 2016, in Manabí Province, the following cases were reported: 5775 cases of DENV, 2509 cases of ZIKV, 339 cases of CHIKV, 21 cases of leptospirosis, 142 cases of typhoid and paratyphoid fever, 2279 cases of pneumonia, and 5 cases of malaria $[59,60]$. This suggests that DCZ infections were among the most common causes of febrile illness, although other infectious pathogens were also reported.

We found that a surprisingly high proportion of individuals with suspected DCZ infections had sought medical care (62.0\%). This is much higher than has been observed in prior studies in Ecuador, which found that DENV infections are greatly underreported due to subclinical or mild clinical presentation of the disease and low health care seeking behavior $[54,61,62]$. The high proportion 
of individuals who had sought health care likely reflects effective coverage of primary medical care by the $\mathrm{MoH}$ and other disaster relief groups post-earthquake.

\subsection{Distress and Arbovirus Symptoms}

We found that certain subgroups were more likely to have suspected DCZ infections if they reported a greater number of psychological distress symptoms, including residents of the periurban community of Bella Vista, women, individuals 40 to 64 years of age, and those who reported not sleeping at home. Bella Vista, with its precarious geography and weak housing construction, experienced the greatest damages to homes. Bella Vista also had the highest prevalence of DCZ symptoms, consistent with the urban habitat preferences of the Ae. aegypti mosquito. These findings suggest that periurban communities exposed to natural disasters face a double burden of psychological distress and arbovirus infections. The effects of stress may have increased people's susceptibility to DCZ infections due to changes in behaviors that lowered their immune response. In a periurban setting, we observed that individuals were exposed to a host of environmental stressors, such as loud noises, which could disrupt their sleeping habits.

Adults (40-64 years) with a greater number of psychological distress symptoms were more likely to have suspected DCZ infections. Adults are generally the heads of their households and thus, were under greater stress to care for themselves and their family during and after the earthquake. During the 2015 CHIKV epidemic, older adults were the group most likely to have acute symptomatic CHIKV infections [54]. This may also have been true for ZIKV, as this was a new infection passing through a completely susceptible population.

Women with a greater number of distress symptoms were also more likely to have suspected DCZ infections. Prior studies suggest that women are at greater risk of psychological distress post-disaster [21]. The average number of distress symptoms in women (mean $=1.2)$ was greater than in men (mean $=0.98$ ), although the differences were not statistically significant. In Ecuador, women are responsible for the health and wellbeing of their families, and prior studies found that stress and depression in Ecuadorian women was associated with excessive social responsibilities [63]. We observed that women leaders were exceptionally stressed in the post-disaster period, due to the demands to care for their families and community, which may have resulted in a lack of self-care. Women may have also had additional fear and/or anxiety around pregnancy and congenital malformations associated with the emerging epidemic of ZIKV. In Ecuador, family planning measures can be difficult to access [64] and elective abortions are criminalized [65]. The burden placed on women who lack adequate access to family planning in ZIKV endemic areas as been documented in similar Latin American countries [66,67].

The association between increased psychological distress and suspected DCZ infections among those who reported not sleeping at home is likely multifactorial. People did not sleep at home if their house was severely damaged and for fear of aftershocks. In the days following the earthquake, community members reported sleeping on the streets wherever they could find space. Afterwards, people constructed makeshift tents or moved into formal encampments set up by relief agencies. These experiences likely increased their exposure to the mosquito vector and resulted in poorer self-care, and psychological distress.

Stress can modulate the immune system through direct and indirect mechanisms [29]. The direct effects of stress on the immune system occur when the brain releases hormones and other substances that affect the immune response. Indirect effects occur when people's behaviors change in response to stressful situations (e.g., changes in sleeping patterns, poor nutrition, substance abuse). The effects of stress on the immune system depends on the nature of the stressor (e.g., acute short-term stress versus chronic stress) and the type of adverse event. For example, loss and bereavement can increase cortisol levels, whereas PTSD can decrease cortisol levels [29]. We postulate that communities affected by the Ecuadorian earthquake simultaneously experienced ongoing loss and PTSD. Additional studies are needed to understand the effects of stress on the immune system and on susceptibility to infectious 
diseases in post-disaster settings. At a minimum, we can say that certain sub-groups appear to be more susceptible to the double burden of psychological distress and arbovirus infection.

\subsection{Limitations}

This study represents the results of a rapid post-disaster health assessment conducted at one time point in four communities affected by the 2016 earthquake in Ecuador. As study participants were asked about their psychological distress and DCZ symptoms during the three-month period post-earthquake, it is possible that there were memory biases. Galea et al. (2005) present the epidemiological challenges of interpreting data on psychological distress collected after disasters [21]. They indicate that in an ideal setting, PTSD would be diagnosed by a mental health professional using the Diagnostic and Statistical Manual of Mental Disorders (DSM) criteria and instruments. However, in many real-world post-disaster settings, public health technicians conduct rapid health evaluations. This evaluation did include many of the key factors in the diagnosis of depression, anxiety and PTSD and was implemented by $\mathrm{MoH}$ technicians to be culturally sensitive and appropriate. However, given the nature of the survey, we were not able to distinguish between varying degrees of psychological distress (e.g., more or less fear or anxiety). For this reason, we report the presence/absence of psychological distress symptoms and the number of symptoms, rather than a definitive psychological diagnosis.

Since the survey was conducted at one time point post-earthquake, we report the point prevalence of psychological distress symptoms and suspected DCZ infections, rather than incidence [21]. A cohort study with data pre-disaster would have provided data on incidence. Surveys could have been conducted in communities with similar social profiles that were not affected by the earthquake; however, it would have been difficult to find such communities, because the 2016 earthquake affected such a large geographic area. Our study was also unique in that it occurred during the time of the first ZIKV epidemic in Ecuador.

Because our research was observational, we report a positive association between the degree of psychological distress and the presence of suspected DCZ infections but we cannot assign causality. Increased stress could increase the likelihood of a viral infection and a viral infection could lead to increased stress, resulting in a positive feedback loop. Longitudinal cohort studies are needed to address this question. Cumulative, long-term stress could be measured via hair cortisol [68-70] combined with validated psychosocial assessment tools to provide much more robust indicators of psychological distress following natural disasters or other stressful events.

\section{Conclusions}

The 2016 earthquake in Ecuador triggered an outbreak of ZIKV in coastal communities. In this study, we assessed whether individuals with high levels of psychological distress reported more symptoms compatible with ZIKV and other arboviral infections three months after the earthquake. The results of this study indicate a positive association between the degree of psychological distress and the presence of suspected arboviral (dengue, chikungunya, Zika) infections in a periurban community, women, adults (40-64 years) and individuals who, three months post-disaster, were still not sleeping at home. Future studies are needed to investigate how psychological distress from catastrophic events influences people's capacity to mount an effective immune response to infectious pathogens, and how infectious diseases affect psychological distress. These findings highlight the need for integrated health responses following natural disasters that include healthcare professionals skilled in assessing and managing infectious diseases and psychological distress.

Supplementary Materials: The following are available online at www.mdpi.com/1660-4601/14/12/1516/s1, Table S1: The frequency and prevalence of chronic health conditions reported by study site.

Acknowledgments: We would like to thank the community members from Bahía de Caráquez who participated in this study and Don Alfredo Harmsen from the Sathyia Sai School in Bahía de Caráquez for supporting this work. We would also like to thank colleagues from the Ministry of Health and disaster relief volunteers who collected the data analyzed in this study and for their overall support of the analysis. 
Author Contributions: Anna M. Stewart-Ibarra conceived of the study. Juan Pablo Molina, David Madden, David Macias Saltos, and Moory M. Romero contributed to the design of survey instruments and data collection. Avriel Diaz assisted with database compilation and editing of the manuscript. Aileen Kenneson and Anna M. Stewart-Ibarra conducted data analyses. Anita Hargrave and Anna M. Stewart-Ibarra drafted the manuscript. All co-authors reviewed and approved the study.

Conflicts of Interest: The authors declare no conflict of interest.

\section{References}

1. USAID. Ecuador-Earthquake. Fact Sheet \#5. Available online: https://www.usaid.gov/sites/default/files / documents/1866/ecuador_eq_fs05_05-06-2016.pdf (accessed on 19 October 2017).

2. Vasquez, D.; Palacio, A.; Nuñez, J.; Briones, W.; Beier, J.C.; Pareja, D.C.; Tamariz, L. Impact of the 2016 Ecuador Earthquake on Zika Virus Cases. Am. J. Public Health 2017, 107, 1137-1142. [CrossRef] [PubMed]

3. World Health Organization. Zika Virus. Available online: http:/ /www.who.int/mediacentre/factsheets/ zika/en/ (accessed on 25 February 2016).

4. National Sub-Secretary for Public Health Surveillance. Zika Gazette SE 38-2017; Ministry of Health of Ecuador: Quito, Ecuador, 2017. Available online: http:/ /www.salud.gob.ec/wp-content/uploads/2015/12/ vvGACETA-ZIKA_SE-38.pdf (accessed on 9 October 2017).

5. World Health Organization. Dengue: Guidelines for Diagnosis, Treatment, Prevention and Control; ISBN 92-4-154787-1. World Health Organization: Geneva, Switzerland, 2009.

6. World Health Organization. Chikungunya. Available online: http://www.who.int/mediacentre/factsheets / fs327/en/ (accessed on 25 February 2016).

7. Alava, A.; Mosquera, C.; Vargas, W.; Real, J. Dengue en el Ecuador 1989-2002. Rev. Ecuat. Hig. Med. Trop. 2005, 42, 11-34.

8. Alava, A.; Suarez, C.; Mosquera, C.; Vargas, I.; Montesdeoca, J. Dengue en el Ecuador: Consideraciones de laboratorio. Rev. Ecuat. Hig. Med. Trop. 1992, 40, 5-22.

9. Gutierrez, E.; Real, J.; Alava, A.; Mosquera, C. Epidemia de Dengue Hemorragico en el Ecuador, 2003. Rev. Ecuat. Hig. Med. Trop. 2005, 42, 35-49.

10. Gonzalez, V.; Jurado, H. Guayaquil: Aedes aegypti, 1740-2007; Servicio Nacional Para La Eradicaccion de Malaria (SNEM): Guayaquil, Ecuador, 2007.

11. Sorenson, C.J.; Borbor-Cordova, M.J.; Calvello-Hynes, E.; Diaz, A.; Lemery, J.; Stewart-Ibarra, A.M. Climate Variability, Vulnerability and Natural Disasters: A Case Study of Zika Virus in Manabi, Ecuador Following the 2016 Earthquake. Geohealth 2017, 1. [CrossRef]

12. Caminade, C.; Turner, J.; Metelmann, S.; Hesson, J.C.; Blagrove, M.S.; Solomon, T.; Morse, A.P.; Baylis, M. Global risk model for vector-borne transmission of Zika virus reveals the role of El Niño 2015. Proc. Natl. Acad. Sci. USA 2017, 114, 119-124. [CrossRef] [PubMed]

13. Muñoz, Á.G.; Thomson, M.C.; Stewart-Ibarra, A.M.; Vecchi, G.A.; Chourio, X.; Nájera, P.; Moran, Z.; Yang, X. Could the Recent Zika Epidemic Have Been Predicted? Front. Microbiol. 2017, 8. [CrossRef] [PubMed]

14. Mordecai, E.; Cohen, J.; Evans, M.V.; Gudapati, P.; Johnson, L.R.; Miazgowicz, K.; Murdock, C.C.; Rohr, J.R.; Ryan, S.J.; Savage, V.; et al. Temperature determines Zika, dengue and chikungunya transmission potential in the Americas. BioRxiv 2016, 63735. [CrossRef]

15. Waring, S.C.; Brown, B.J. The threat of communicable diseases following natural disasters: A public health response. Disaster Manag. Response 2005, 3, 41-47. [CrossRef] [PubMed]

16. Kouadio, I.K.; Aljunid, S.; Kamigaki, T.; Hammad, K.; Oshitani, H. Infectious diseases following natural disasters: Prevention and control measures. Expert Rev. Anti Infect. Ther. 2012, 10, 95-104. [CrossRef] [PubMed]

17. Domercant, J.W.; Guillaume, F.D.; Marston, B.J.; Lowrance, D.W. Update on progress in selected public health programs after the 2010 earthquake and cholera epidemic-Haiti, 2014. MMWR Morb. Mortal. Wkly. Rep. 2015, 64, 137-140. [PubMed]

18. Qadri, F.; Khan, A.I.; Faruque, A.S.G.; Begum, Y.A.; Chowdhury, F.; Nair, G.B.; Salam, M.A.; Sack, D.A.; Svennerholm, A.-M. Enterotoxigenic Escherichia coli and Vibrio cholerae diarrhea, Bangladesh, 2004. Emerg. Infect. Dis. 2005, 11, 1104. [CrossRef] [PubMed]

19. Zhang, Z.; Shi, Z.; Wang, L.; Liu, M. One year later: Mental health problems among survivors in hard-hit areas of the Wenchuan earthquake. Public Health 2011, 125, 293-300. [CrossRef] [PubMed] 
20. Chen, C.-C.; Yeh, T.-L.; Yang, Y.K.; Chen, S.-J.; Lee, I.H.; Fu, L.S.; Yeh, C.Y.; Hsu, H.C.; Tsai, W.L.; Cheng, S.H.; et al. Psychiatric morbidity and post-traumatic symptoms among survivors in the early stage following the 1999 earthquake in Taiwan. Psychiatry Res. 2001, 105, 13-22. [CrossRef]

21. Galea, S.; Nandi, A.; Vlahov, D. The Epidemiology of Post-Traumatic Stress Disorder after Disasters. Epidemiol. Rev. 2005, 27, 78-91. [CrossRef] [PubMed]

22. Goenjian, A.K.; Steinberg, A.M.; Najarian, L.M.; Fairbanks, L.A.; Tashjian, M.; Pynoos, R.S. Prospective study of posttraumatic stress, anxiety and depressive reactions after earthquake and political violence. Am. J. Psychiatry 2000, 157, 911. [CrossRef] [PubMed]

23. Zhang, W.; Liu, H.; Jiang, X.; Wu, D.; Tian, Y. A longitudinal study of posttraumatic stress disorder symptoms and its relationship with coping skill and locus of control in adolescents after an earthquake in China. PLOS ONE 2014, 9, e88263. [CrossRef] [PubMed]

24. Farooqui, M.; Quadri, S.A.; Suriya, S.S.; Khan, M.A.; Ovais, M.; Sohail, Z.; Shoaib, S.; Tohid, H.; Hassan, M. Posttraumatic stress disorder: A serious post-earthquake complication. Trends Psychiatry Psychother. 2017, 39, 135-143. [CrossRef] [PubMed]

25. American Psychiatric Association. Diagnostic and Statistical Manual of Mental Disorders (DSM- $\left.{ }^{\circledR}\right)$; American Psychiatric Association Publishing: Arlington, VA, USA, 2013.

26. Lima, B.R.; Chavez, H.; Samaniego, N.; Pompei, M.S.; Pai, S.; Santacruz, H.; Lozano, J. Disaster severity and emotional disturbance: Implications for primary mental health care in developing countries. Acta Psychiatr. Scand. 1989, 79, 74-82. [CrossRef] [PubMed]

27. Lima, B.R. Primary Mental Health Care for Disaster Victims in Developing Countries; FMHI Publications: Tampa, FL, USA, 1986.

28. Lima, B.R.; Chávez, H.; Samaniego, N.; Pai, S. Psychiatric disorders among emotionally distressed disaster victims attending primary mental health clinics in Ecuador. Bull. Pan Am. Health Organ. 1992, 26, 60-66. [PubMed]

29. Segerstrom, S.C.; Miller, G.E. Psychological Stress and the Human Immune System: A Meta-Analytic Study of 30 Years of Inquiry. Psychol. Bull. 2004, 130, 601-630. [CrossRef] [PubMed]

30. Glaser, R.; Rice, J.; Sheridan, J.; Fertel, R.; Stout, J.; Speicher, C.; Pinsky, D.; Kotur, M.; Post, A.; Beck, M.; et al. Stress-related immune suppression: Health implications. Brain Behav. Immun. 1987, 1, 7-20. [CrossRef]

31. Irwin, M. Stress-induced immune suppression: Role of brain corticotropin releasing hormone and autonomic nervous system mechanisms. Adv. Neuroimmunol. 1994, 4, 29-47. [CrossRef]

32. Cohen, S.; Williamson, G.M. Stress and infectious disease in humans. Psychol. Bull. 1991, 109, 5. [CrossRef] [PubMed]

33. Cohen, S.; Tyrrell, D.A.; Smith, A.P. Psychological stress and susceptibility to the common cold. N. Engl. J. Med. 1991, 325, 606-612. [CrossRef] [PubMed]

34. Joob, B.; Wiwanitkit, V. Serum cortisol in dengue and dengue hemorrhagic fever: Is there any clinical implication? Asian Pac. J. Trop. Dis. 2014, 4, 313-314. [CrossRef]

35. Christ-Crain, M.; Stolz, D.; Jutla, S.; Couppis, O.; Müller, C.; Bingisser, R.; Schuetz, P.; Tamm, M.; Edwards, R.; Müller, B.; et al. Free and total cortisol levels as predictors of severity and outcome in community-acquired pneumonia. Am. J. Respir. Crit. Care Med. 2007, 176, 913-920. [CrossRef] [PubMed]

36. Namazi, M.R. The cellular immunodeficiency associated with post-traumatic stress disorder may be the result of sympathetic overactivity and be correctable by beta-2-blockers. Neuroendocrinol. Lett. 2003, 24, 468-473. [PubMed]

37. Kusnecov, A.V.; Grota, L.J.; Schmidt, S.G.; Bonneau, R.H.; Sheridan, J.F.; Glaser, R.; Moynihan, J.A. Decreased herpes simplex viral immunity and enhanced pathogenesis following stressor administration in mice. J. Neuroimmunol. 1992, 38, 129-137. [CrossRef]

38. Bonneau, R.H.; Sheridan, J.F.; Feng, N.; Glaser, R. Stress-induced suppression of herpes simplex virus (HSV)-specific cytotoxic T lymphocyte and natural killer cell activity and enhancement of acute pathogenesis following local HSV infection. Brain Behav. Immun. 1991, 5, 170-192. [CrossRef]

39. Johnson, R.R.; Storts, R.; Welsh, T.H.; Welsh, C.J.R.; Meagher, M.W. Social stress alters the severity of acute Theiler's virus infection. J. Neuroimmunol. 2004, 148, 74-85. [CrossRef] [PubMed]

40. Pan American Health Organization; World Health Organization. Dengue: Annual Cases Reported of Dengue. PAHO/WHO Data, Maps and Statistics. Available online: http:/ / www.paho.org/hq/index.php?option= com_topics\&view=rdmore\&cid=6290\&Itemid=40734 (accessed on 18 July 2017). 
41. Pan American Health Organization; World Health Organization. Chikungunya: Data, Maps and Statistics. Available online: http://www.paho.org/hq/index.php?option=com_topics\&view=readall\&cid=5927\& Itemid=40931\&lang=en (accessed on 28 September 2017).

42. Pan American Health Organization; World Health Organization. Zika Cumulative Cases. Available online: http: / / www.paho.org/hq/index.php?option=com_content\&view=article\&id=12390\&Itemid=42090\&lang=en (accessed on 21 February 2017).

43. Cairo, J.B.; Dutta, S.; Nawaz, H.; Hashmi, S.; Kasl, S.; Bellido, E. The Prevalence of Posttraumatic Stress Disorder among Adult Earthquake Survivors in Peru. Disaster Med. Public Health Prep. 2010, 4, $39-46$. [CrossRef] [PubMed]

44. Cao, H.; McFarlane, A.C.; Klimidis, S. Prevalence of psychiatric disorder following the 1988 Yun Nan (China) earthquake. Soc. Psychiatry Psychiatr. Epidemiol. 2003, 38, 204-212. [CrossRef] [PubMed]

45. Sharan, P.; Chaudhary, G.; Kavathekar, S.A.; Saxena, S. Preliminary report of psychiatric disorders in survivors of a severe earthquake. Am. J. Psychiatry 1996, 153, 556-558. [PubMed]

46. Carr, V.J.; Lewin, T.J.; Webster, R.A.; Kenardy, J.A.; Hazell, P.L.; Carter, G.L. Psychosocial sequelae of the 1989 Newcastle earthquake: II. Exposure and morbidity profiles during the first 2 years post-disaster. Psychol. Med. 1997, 27, 167-178. [CrossRef] [PubMed]

47. Chen, S.-H.; Wu, Y.-C. Changes of PTSD Symptoms and School Reconstruction: A Two-year Prospective Study of Children and Adolescents after the Taiwan 921 Earthquake. Nat. Hazards 2006, 37, 225-244. [CrossRef]

48. Şahin, N.H.; Batıgün, A.D.; Yılmaz, B. Psychological symptoms of Turkish children and adolescents after the 1999 earthquake: Exposure, gender, location and time duration. J. Trauma. Stress 2007, 20, 335-345. [CrossRef] [PubMed]

49. Chang, C.-M.; Connor, K.M.; Lai, T.-J.; Lee, L.-C.; Davidson, J.R.T. Predictors of posttraumatic outcomes following the 1999 Taiwan earthquake. J. Nerv. Ment. Dis. 2005, 193, 40-46. [CrossRef] [PubMed]

50. Ekşi, A.; Braun, K.L.; Ertem-Vehid, H.; Peykerli, G.; Saydam, R.; Toparlak, D.; Alyanak, B. Risk factors for the development of PTSD and depression among child and adolescent victims following a 7.4 magnitude earthquake. Int. J. Psychiatry Clin. Pract. 2007, 11, 190-199. [CrossRef] [PubMed]

51. Karakaya, I.; Ağaoğlu, B.; Coşkun, A.; Sişmanlar, S.G.; Yildiz Oc, O. The symptoms of PTSD, depression and anxiety in adolescent students three and a half years after the Marmara earthquake. Turk. Psikiyatri. Derg. Turk. J. Psychiatry 2004, 15, 257-263.

52. Hsu, C.-C.; Chong, M.-Y.; Yang, P.; Yen, C.-F. Posttraumatic stress disorder among adolescent earthquake victims in Taiwan. J. Am. Acad. Child Adolesc. Psychiatry 2002, 41, 875-881. [CrossRef] [PubMed]

53. Del Brutto, O.H.; Mera, R.M.; Del Brutto, V.J.; Maestre, G.E.; Gardener, H.; Zambrano, M.; Wright, C.B. Influence of depression, anxiety and stress on cognitive performance in community-dwelling older adults living in rural Ecuador: Results of the Atahualpa Project. Geriatr. Gerontol. Int. 2015, 15, 508-514. [CrossRef] [PubMed]

54. Stewart-Ibarra, A.M.; Ryan, S.J.; Kenneson, A.; King, C.A.; Abbott, M.; Barbachano-Guerrero, A.; Beltran-Ayala, E.; Borbor-Cordova, M.J.; Cardenas, W.; Cueva, C.; et al. The burden of dengue and chikungunya in southern coastal Ecuador: Epidemiology, clinical presentation and phylogenetics from a prospective study in Machala in 2014 and 2015. BioRxiv 2017, 102004. [CrossRef]

55. Hayes, C.G.; Phillips, I.A.; Callahan, J.D.; Griebenow, W.F.; Hyams, K.C.; Wu, S.-J.; Watts, D.M. The Epidemiology of Dengue Virus Infection among Urban, Jungle and Rural Populations in the Amazon Region of Peru. Am. J. Trop. Med. Hyg. 1996, 55, 459-463. [CrossRef] [PubMed]

56. Gubler, D.J. Epidemic dengue/dengue hemorrhagic fever as a public health, social and economic problem in the 21st century. Trends Microbiol. 2002, 10, 100-103. [CrossRef]

57. Stewart-Ibarra, A.M.; Ryan, S.J.; Beltrán, E.; Mejía, R.; Silva, M.; Muñoz, Á. Dengue Vector Dynamics (Aedes aegypti) Influenced by Climate and Social Factors in Ecuador: Implications for Targeted Control. PLoS ONE 2013, 8, e78263. [CrossRef] [PubMed]

58. Gulati, S.; Maheshwari, A. Dengue fever-like illnesses: How different are they from each other? Scand. J. Infect. Dis. 2012, 44, 522-530. [CrossRef] [PubMed]

59. National Sub-Secretary for Public Health Surveillance. Weekly Epidemiological Gazette No. 52, 2016 2017; Ministry of Health of Ecuador: Quito, Ecuador, 2017. Available online: http://www.salud.gob.ec/wpcontent/uploads/2013/02/GACETA-GENERAL-SE52.pdf (accessed on 18 October 2017). 
60. National Sub-Secretary for Public Health Surveillance. Anuario de Vigilancia Epidemiológica 1994-2016 Enfermedades Trasmitidas por Vectores; Ministry of Health of Ecuador: Quito, Ecuador, 2017. Available online: https://public.tableau.com/views/EnfermeddaesTropicales_vectoriales-2014/ANUARIO? $\% 3$ Aembed=y\&\%3AshowVizHome=no\&\%3Adisplay_count=y\&\%3Adisplay_static_image=y\& $\% 3$ AbootstrapWhenNotified=true (accessed on 18 October 2017).

61. Handel, A.S.; Ayala, E.B.; Borbor-Cordova, M.J.; Fessler, A.G.; Finkelstein, J.L.; Espinoza, R.X.R.; Ryan, S.J.; Stewart-Ibarra, A.M. Knowledge, attitudes and practices regarding dengue infection among public sector healthcare providers in Machala, Ecuador. Trop. Dis. Travel Med. Vaccines 2016, 2, 8. [CrossRef] [PubMed]

62. Stewart-Ibarra, A.M.; Luzadis, V.A.; Borbor-Cordova, M.; Silva, M.; Ordonez, T.; Beltran Ayala, E.; Ryan, S.J. A social-ecological analysis of community perceptions of dengue fever and Aedes aegypti in Machala, Ecuador. BMC Public Health 2014, 14, 1135. [CrossRef] [PubMed]

63. Finerman, R.F. The burden of responsibility: Duty, depression and nervios in Andean Ecuador. Health Care Women Int. 1989, 10, 141-157. [CrossRef] [PubMed]

64. Beckwith, J. Knowledge, attitudes and practices in reproductive and sexual health: Valle de los Chillos, Rumiñahui County, Province of Pichincha, Ecuador. McGill J. Med. MJM 2006, 9, 119. [PubMed]

65. Ortiz-Prado, E.; Simbaña, K.; Gómez, L.; Stewart-Ibarra, A.M.; Scott, L.; Cevallos-Sierra, G. Abortion, an increasing public health concern in Ecuador, a 10-year population-based analysis. Pragmat. Obs. Res. 2017, 8, 129-135. [CrossRef] [PubMed]

66. Harris, L.H.; Silverman, N.S.; Marshall, M.F. The paradigm of the paradox: Women, pregnant women and the unequal burdens of the Zika virus pandemic. Am. J. Bioeth. 2016, 16, 1-4. [CrossRef] [PubMed]

67. Roa, M. Zika virus outbreak: Reproductive health and rights in Latin America. Lancet 2016, $387,843$. [CrossRef]

68. Russell, E.; Koren, G.; Rieder, M.; Van Uum, S. Hair cortisol as a biological marker of chronic stress: Current status, future directions and unanswered questions. Psychoneuroendocrinology 2012, 37, 589-601. [CrossRef] [PubMed]

69. Staufenbiel, S.M.; Penninx, B.W.; Spijker, A.T.; Elzinga, B.M.; van Rossum, E.F. Hair cortisol, stress exposure and mental health in humans: A systematic review. Psychoneuroendocrinology 2013, 38, 1220-1235. [CrossRef] [PubMed]

70. Steudte, S.; Kirschbaum, C.; Gao, W.; Alexander, N.; Schönfeld, S.; Hoyer, J.; Stalder, T. Hair cortisol as a biomarker of traumatization in healthy individuals and posttraumatic stress disorder patients. Biol. Psychiatry 2013, 74, 639-646. [CrossRef] [PubMed] 